\title{
ASSESSING THE AWARENESS AND CONSCIOUSNESS OF YOUNG STUDENIS ABOUT THE ROLE OF NUTRITION IN THE DEVELOPMENT OF NON-INFECTIOUS DISEASES
}

\author{
Serdiuk A.M., Gulich M.P., Petrenko O.D., Liubarska L.S., Koblianska A.V.
}

\section{ОЦПНКА ОБІЗНАНОСТІ ТА УСВДДОМЛЕННЯ СТУДЕНТСЬКОЮ МОЛОДДЮ РОЛІ ХАРУУВАННЯ У РОЗВИТКУ НЕЕНФЕКЩИЙНИХ ЗАХВОРЮВАНЫЬ}

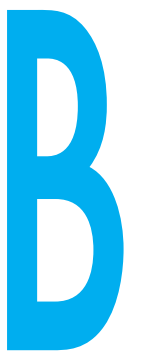

СЕРДЮК А.М. ГУЛІЧ М.П. ПЕТРЕНКО О.Д. ЛЮБАРСЬКА Л.С., КОБЛЯНСЬКА А.В ДУ “Інститут громадського здоров'я ім. О.М. Марзєєва НАМН України", м. Київ

\section{Ключові слова: соціологічне опитування, неінфекційні захворювання, харчування студенти.}

сесвітня організація охорони здоров'я визначає зростання хронічних неінфекційних захворювань як величезну світову проблему [6]. Ця проблема не обійшла і Україну. Неінфекційні захворювання (НI3) в Україні нині вже набули характеру епідемії, що є серйозною проблемою громадського здоров'я. Особливу загрозу становить те, що вік розвитку хвороб значно зменшився. Саме тому актуальним ниністає питання запобігання розвиткові НІЗ у молоді, оскільки саме ця верства населення поєднує у собі основний інтелектуальний, творчий та репродуктивний потенціал країни. Особливою частиною молоді $€$ студентська молодь, для якої характерні високі навчальні навантаження, пов'язані з підвищенням рівня розумового напруження та психоемоційного стресу; різка зміна способу життя; зміна соціальних відносин; схильність до ризикової поведінки тощо [5].
Крім того, молодий організм з фізіологічної точки зору зазнає подальшого росту та розвитку, що зумовлює значну вразливість до незбалансованого харчування, дефіциту вітамінів та мікроелементів, недостатньої фізичної активності, наслідків тютюнопаління та зловживання алкоголем.

За даними досліджень, проведених з цього приводу, стан здоров'я студентів $\epsilon$ незадовільним та має негативні тенденції. Також встановлено, що стан здоров'я молоді погіршується під час навчання у вишах [3].

Відомо, що одним 3 найвагоміших чинників формування та збереження здоров'я людини є спосіб життя, а вирішальну роль у розвитку хронічних неінфекційних захворювань відіграють саме поведінкові фактори, які і характеризують спосіб життя людини. Це - передусім нераціональне харчування, низька фізична активність, тютюнопаління, зловживання алкоголем. Слід зазначити, що поведінкові моделі, як прави-
ОЦЕНКА ОСВЕДОМЛЕННОСТИ И ОСОЗНАНИЯ СТУДЕНЧЕСКОЙ МОЛОДЕЖЬЮ РОЛИ ПИТАНИЯ В РАЗВИТИИ НЕИНФЕКЦИОННЫХ ЗАБОЛЕВАНИЙ

Сердюк А.М., Гулич М.П., Петренко Е.Д., Любарская Л.С., Коблянская А.В. ГУ "Институт общественного здоровья им. А.Н. Марзеева НАМН Украины”, г. Киев

Цель работы - исследование особенностей осведомленности и осознания студентами высших учебных заведений различного профиля касательно здорового образа жизни и угрозы для здоровья факторов риска развития НИЗ, прежде всего питания.

Материалы и методы: проведен социологический опрос среди студентов высших учебных заведений Украины касательно уровней осведомленности, а также распространенности отдельных факторов развития неинфекционных заболеваний. В исследовании приняли участие 430 студентов Киевского национального торгово-экономического университета и 217 студентов Сумского государственного педагогического университета. Использованы социологиче- ский и статистический методы.

Результаты. Установлен высокий уровень осведомленности студентов касательно основных факторов развития неинфекционных заболеваний, в частности питания. Однако их осведомленность не ведет к осознанию ими угрозы этих факторов для здоровья.

Изучена распространенность негативных факторов пищевого поведения студентов, таких как потребление чрезмерных количеств сахара, соли, газированных напитков, спредов и маргаринов, недостаток свежих овощей и фруктов в питании и т.д. Показано существенное различие показателей пищевого поведения студентов разнопрофильных вузов.

Вывод: обоснована необходимость дальнейшей доработки и усовершенствования информационных и учебных программ для студентов с целью улучшения их осведомленности и осознания опасности факторов риска развития неинфекционных заболеваний.

Ключевые слова: социологический опрос, неинфекционные заболевания, питание, студенты.

() Сердюк А.М., Гуліч М.П., Петренко О.Д., Любарська Л.С., Коблянська А.В. СТАТТЯ, 2019. 
Автори виділяють захворювання органів ШКТ, якими студенти страждають найчастіше. Це - передусім гастрити і дуоденіти. Захворюваність на них становить 477,0 на 100 тис. студентів, поширеність - 2954,6 на 100 тис., що значно перевищує таку серед дорослого населення, де захворюваність становить 148,3 на 100 тис. населення, поширеність 2453,3 на 100 тис. [1].

При вивченні у ретроспективі захворюваності студентів двох різнопрофільних вищих навчальних закладів (ВНЗ) (технічного та економічного) встановлено, що поширеність захворювань органів кровообігу збільшилась у студентів обох ВНЗ, але відсоток залежить від профілю ВНЗ. Так, у студентів технічного ВНЗ захворюваність органів кровообігу за 20102015 роки збільшилася на $22,9 \%$, а у студентів ВНЗ економічного профілю - на 67,5\%. Рівень зростання ендокринних захворювань також різниться: у студентів технічного профілю на $46,1 \%$, у студентів економічного профілю - на 89,8\% [2] .

Виходячи 3 цього одним 3 важливих завдань підготовки студентів у вишах має бути запровадження здоров'язбережних дисциплін для формування у них культури здорового способу життя та засвоєння основних знань щодо чинників ризику розвитку хронічних неінфекційних захворювань.

Проте більшість вищих навчальних закладів (ВНЗ), профіль яких не стосується здоров'я людини, взагалі не передбачає у навчальних планах подібні програми. На- слідком такого процесу є абсолютна або часткова непоінформованість значної частини студентів щодо здорового способу життя та ризику розвитку HI3.

Тому важливим завданням щодо запобігання розвитку неінфекційних захворювань серед студентської молоді $€$ розробка та втілення ефективних, адекватних та сучасних здоров'язбережних заходів, які потребують вивчення обізнаності та усвідомлення студентами ролі здорового способу життя та різних чинників розвитку НІЗ у формуванні їхнього здоров'я.

Метою роботи було дослідження особливостей обізнаності та усвідомлення студентами вишів різного профілю щодо здорового способу життя i загрози для здоров'я основних факторів ризику розвитку НІЗ, насамперед харчування.

Матеріали та методи досліджень. Для вивчення рівнів обізнаності, а також поширеності серед студентів окремих факторів розвитку НІЗ застосовувалася розроблена фахівцями ду "Інститут громадського здоров'я імені Марзєєва О.М. НАМН України" анкета. При розробці даної анкети враховано загальні принципи і правила ВООЗ, міжнародні вимоги до документів, що можуть бути використані при проведенні дослідження [4], дані аналізу літератури щодо факторів ризику. Анкета містила питання, поділені на окремі групи, що стосувалися певних факторів розвитку НІ3: раціональне харчування та режим харчування, підтримка фізичної вить 7138,5 на 100 тис., серед дорослих - 9244,2 на 100 тис.

Частка студентів, яким відомо про вплив основних факторів розвитку НІ3, \%

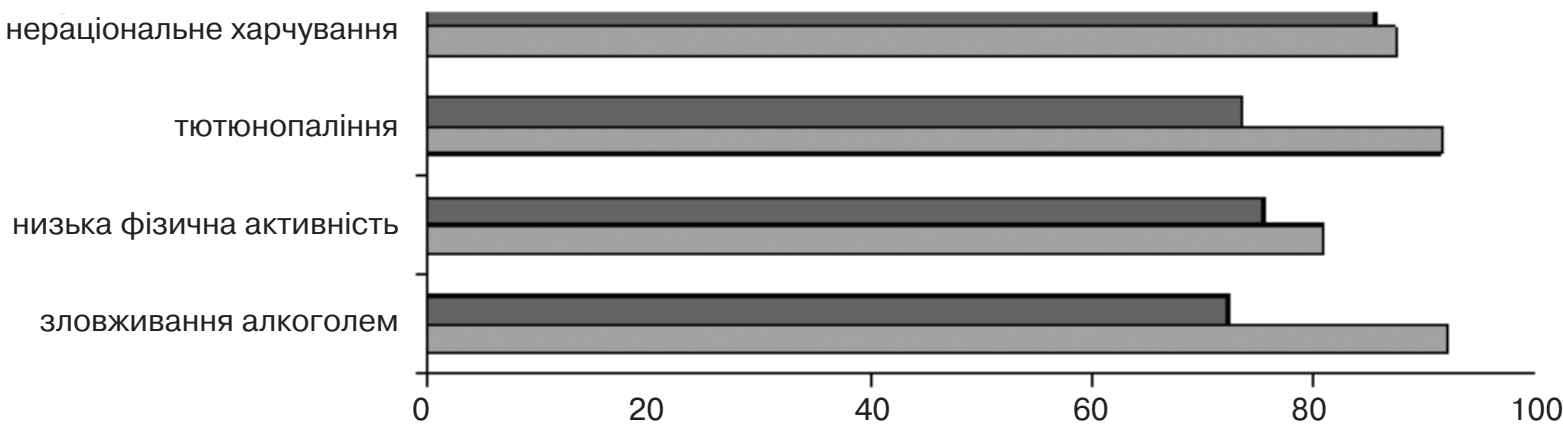


ASSESSING THE AWARENESS AND CONSCIOUSNESS OF YOUNG STUDENTS ABOUT THE ROLE OF NUTRITION IN THE DEVELOPMENT OF NON-INFECTIOUS DISEASES

Serdiuk A.M., Gulich M.P., Petrenko O.D., Liubarska L.S., Koblianska A.V.

State Institution "O.M. Marzeiev Institute for Public Health, NAMS of Ukraine" Kyiv

The purpose of the work is to study the awareness and consciousness of students of higher educational institutions of various profiles in healthy lifestyle and a threat to health of risk factors for the development of non-infectious diseases, in particular, nutrition.

Materials and methods: a sociological survey was conducted among students of higher educational institutions of Ukraine on the levels of awareness and prevalence of certain factors in the development of non-infectious diseases. The study involved 430 students of the Kyiv National University of Trade and Economics and 217 stu- dents of Sumy State Pedagogical University. Used methods: sociological, statistical.

Results: A high level of students' awareness of the main factors in the development of non-infectious diseases, in particular nutrition, was established. However, their awareness does not lead them to realize the threat to the health of these factors. The prevalence of negative factors in students' eating behavior, such as the consumption of excessive amounts of sugar, salt, carbonated drinks, spreads and margarines, lack of fresh vegetables and fruits in the diet, etc., was studied. It shows a significant difference in the indicators of the eating behavior of students from different universities.

Conclusion: the need for further development and improvement of information and training programs for students to improve their awareness and awareness of the risk factors for the development of noninfectious diseases has been substantiated.

Keywords: sociological survey, non-infectious diseases, nutrition, students. форми, заняття спортом, тютюнопаління, зловживання алкоголем, прийом наркотиків тощо. Питання містили декілька варіантів відповідей.

У дослідженні взяли участь 430 студентів Київського національного торгово-економічного університету (КНТЕУ) (напрям підготовки - харчова технологія та товарознавство) та 217 студентів Сумського державного педагогічного університету (СумДПУ). Нами обрано для участі в анкетуванні саме ці групи студентів, оскільки у майбутньому фахівці 3 харчових технологій, товарознавці будуть реалізовувати політику здорового харчування у сфері громадського харчування та формувати пропозицію на ринку харчування, а педагогічні працівники у майбутньому мають стати джерелом знань для дітей щодо формування здорового способу життя.

Отримані дані піддано статистичному аналізу загальноприйнятими методами.

Результати та їх обговорення. За даними анкетування, проведеного серед студентів КНТЕУ та СумДПУ, визначено рівень обізнаності студентів щодо основних факторів розвитку НІЗ (рис.). Так, встановлено, що переважна більшість опитаних виявляє обізнаність щодо негативного впливу факторів розвитку НІЗ на стан здоров'я.

Наведені дані свідчать про високу обізнаність студентів щодо негативних наслідків нераціонального харчування, яка практично не залежить від навчального профілю ВНЗ. Негативний вплив нераціонального харчування $є$ відомим для 87,4\% студентів КНТЕУ та 85,6\% студентів СумДПУ. Лише $12,6 \%$ опитаних, які навчаються у KHTEУ, та $14,4 \%$ студентів СумДПУ не знають про такий фактор розвитку хронічних неінфекційних захворювань. Слід відзначити суттєву різницю щодо показників обізнаності студентів цих ВНЗ про ризик тютюнопаління, зловживання алкоголем та низьку фізичну активність.

Зважаючи на це належало визначити, чи враховують вони ці знання у своєму житті. Іншими словами, постало питання: чи усвідомлюють вони ризик для здоров'я вказаних поведінкових факторів, зокрема загрози нераціонального харчування.
Порівняння даних, отриманих у ході анкетування, дозволило встановити особливості харчування студентів вищих навчальних закладів.

Частка осіб, які споживають щоденно свіжі овочі та фрукти, серед опитаних студентів КНТЕУ становила 74,2\%, серед студентів СумДПУ - 68,5\% (табл. 1). При цьому встановлено, що близько чверті респондентів, які навчаються у KHTEУ (25,8\%), та близько третини студентів СумДПУ $(31,5 \%)$ не споживають свіжі овочі та фрукти щодня.

За даними анкетування, частка осіб, раціон харчування яких не містить щоденно свіжих овочів та фруктів, виявилася вищою серед опитаних студентів СумДПУ.

Споживання цукру оцінювалося за кількістю ложок цукру,

Таблиця 1

\section{Споживання фруктів та овочів студентами КНТЕУ та СумДПУ, \%}

\begin{tabular}{|l|c|c|}
\hline \multirow{2}{*}{\multicolumn{1}{|c|}{ Навчальний заклад }} & \multicolumn{2}{|c|}{ Відповіді студентів, \% } \\
\cline { 2 - 3 } & Так & $\mathrm{Hi}$ \\
\hline КНТЕУ & 74,2 & 25,8 \\
\hline СумДПУ & 68,5 & 31,5 \\
\hline
\end{tabular}

Таблиця 2

Розподіл відповідей студентів щодо кількості
споживання цукру студентами КНТЕУ та СумДПУ, \%

\begin{tabular}{|l|c|c|}
\hline $\begin{array}{c}\text { Кількість ложок цукру споживають 3 } \\
\text { гарячими напоями - чай чи кава }\end{array}$ & $\begin{array}{c}\text { К-ть студентів } \\
\text { КНТЕУ, \% }\end{array}$ & $\begin{array}{c}\text { К-ть студентів } \\
\text { СумдПУ, \% }\end{array}$ \\
\hline 1 ложка & 19,8 & 27,3 \\
\hline 2 ложка & 33,3 & 40,1 \\
\hline 3 ложки & 7,8 & 9,5 \\
\hline Без цукру & 39,1 & 22,7 \\
\hline
\end{tabular}


яку студенти додають до гарячих напоїв - чаю або кави (табл. 2). Слід зазначити, що рівень споживання цукру серед студентів СумДПУ дещо вищій порівняно зі студентами КНТЕУ. Так, частка студентів які споживають цукор, додаючи його до гарячих напоїв, серед опитаних студентів СумДПУ становить 76,9\%, що на 16,0\% перевищує аналогічний показник серед студентів КНТЕУ $(60,9 \%)$.

За кількістю ложок цукру, що додаються до чаю або кави, частка студентів СумДПУ, які додають до гарячих напоїв 1 ложку цукру, перевищує відповідний показник серед студентів КНТЕУ на 7,5\%, 2 ложки - на 6,8\%, 3 ложки - на 1,7\%. При цьому майже 40\% студентів КНTEУ споживають напої без цукру проти майже 23\% студентів СумДПУ.

Солодкі газовані напої споживають 75\% студентів КНТЕУ та 82,9\% студентів СумДПУ (табл. 3). Порівнюючи отримані дані, слід зазначити, що частка осіб, які ствердно відповіли на запитання щодо споживання солодких газованих напоїв, серед студентів СумДПУ перевищує аналогічну частку студентів КНТЕУ на $11 \%$.

Частка осіб, які споживають солодкі газовані напої іноді,

\section{Споживання солодких газованих напоїв студентами КНТЕУ та СУмДПУ, \%}

\begin{tabular}{|l|c|c|c|}
\hline \multirow{2}{*}{ Навчальний заклад } & \multicolumn{3}{|c|}{ Відповіді студентів, \% } \\
\cline { 1 - 4 } & Так & $\mathrm{Hi}$ & Іноді \\
\hline КНТЕУД & 33,8 & 25,0 & 41,2 \\
\hline СумДПУ & 45,4 & 17,1 & 37,5 \\
\hline
\end{tabular}

Споживання маргаринів та спредів студентами КНТЕУ та СумдпУ, \%

\begin{tabular}{|l|c|c|}
\hline \multirow{2}{*}{ Навчальний заклад } & \multicolumn{2}{|c|}{ Відповіді студентів, \% } \\
\cline { 2 - 3 } & Так & $\mathrm{Hi}$ \\
\hline КНТЕУ & 35,2 & 64,8 \\
\hline СумДПУ & 26,5 & 73,5 \\
\hline
\end{tabular}

Розподіл відповідей щодо кількості споживання солі студентами КНТЕУ та СумДПУ, \%

\begin{tabular}{|l|c|c|}
\hline $\begin{array}{c}\text { Розподіл споживання } \\
\text { солі на добу, г }\end{array}$ & $\begin{array}{c}\text { К-ть студентів КHТЕУ, } \\
\%\end{array}$ & $\begin{array}{c}\text { К-ть студентів } \\
\text { СумДПу, \% }\end{array}$ \\
\hline 5 & 70,5 & 73,6 \\
\hline 25 & 24,8 & 25,0 \\
\hline 35 & 3,5 & 0 \\
\hline$>35$ & 1,2 & 1,4 \\
\hline
\end{tabular}

осіб, які споживають сіль на рівні 35 г (3,5\%), яка серед студентів СумДПУ відсутня. Відносна кількість осіб, які споживають сіль у кількості понад 35 г на добу, серед студентів обох вишів незначна та суттєво не відрізняється.

Також нами було проведено порівняльне вивчення отриманих даних щодо нераціонального харчування з урахуванням обізнаності та статі опитаних студентів.

При розподілі отриманих даних встановлено, що порівняно з обізнаними дівчатами із КНТЕУ студентки СумДПУ більше ніж в 1,5 рази споживають цукор у надмірних кількостях 43,0\% проти 29,0\% (табл. 6).

При оцінці отриманих даних 3 урахуванням обізнаності серед юнаків слід зазначити, що порівняно 3 хлопцями-студентами КНТЕУ студенти СумДПУ менше споживають солодких газованих напоїв. Серед них також суттєво більша частка осіб (в 1,4 рази), які не споживають щоденно свіжі овочі та фрукти (табл. 7).

Проведені дослідження показали, що незважаючи на досить високу обізнаність студентів щодо негативних наслідків нераціонального харчування далеко не усі вони усвідомлюють та мотивовані діяти відповідно до наявних знань.

На підставі власних досліджень та за даними літератури встановлено, що у навчальних програмах ВНЗ існують суттєві відмінності викладання здоров'язбережних дисциплін у системі вищої школи. Нерідко у навчальних програмах підготовки фахівців у галузях знань, що не належать до наук про людину, взагалі відсутні такі дисципліни. Більшість ВНЗ, навчальний профіль яких не стосується здоров'я людини, взагалі не включають до навчального плану подібні програми, або знання у них відображаються частково та однобоко, відповідно до вимог певної професії. Наслідком такого процесу $є$ низький рівень усвідомлення значною кількістю студентів ролі факторів ризиків розвитку НІЗ, зокрема нераціонального харчування.

Тому одним 3 важливих завдань підготовки студентів у вищих навчальних закладах 
має бути підвищення усвідомлення студентською молоддю ролі нераціонального харчування як фактора розвитку НІЗ, формування у них культури здорового способу життя.

\section{Висновки}

1. Встановлено високий рівень обізнаності студентів обох ВНЗ щодо основних факторів розвитку НІЗ, зокрема нераціонального харчування.

Проте їхня обізнаність не призводить до усвідомлення ними загрози цих факторів для здоров'я.

2. Вивчено поширеність негативних чинників харчової поведінки студентів, зокрема споживання надмірних кількостей цукру, солі, газованих напоїв, спредів та маргаринів, нестача свіжих овочів та фруктів у харчуванні тощо. Показано суттєву різницю щодо показників харчової поведінки студентів різнопрофільних ВНЗ.

3. Встановлено необхідність подальшого доопрацювання та удосконалення освітніх та навчальних програм для студентів 3 метою покращання їхньої обізнаності та усвідомлення небезпеки основних поведінкових факторів ризику розвитку НІЗ з точки зору збереження подальшого здоров'я. ЛІТЕРАТУРА

1. Адамович І.В., Вовк К.В., Літвін О.І., Ніколенко Є.Я. та ін. Аналіз захворюваності хвороб органів травлення у студент- ській популяції та профілактичні заходи їх подолання. Актуальні проблеми сучасної медицини. 2018. Т. 18, вип. 3 (63). С. 5-9.

2. Церковна О., Барибіна Л., Філенко Л. та ін. Аналіз структури захворюваності студентів різнопрофільних вишів для пошуку шляхів оптимізації фізичного виховання.

Спортивна наука України. 2017. № 2 (78). С. 47-56.

3. Зиновьев Н.А, Зиновьев А.А., Купреев М.В., Святченко П.Б Информированность студентов технического вуза о параметрах здорового образа жизни. Ученые записки университета Лесгафта. 2015. № 11 (129). С. 42-47.

4. Краткий опросник ВОЗ для оценки качества жизни. The World Health Organization Quality of Life (WHOQOL) BREF. 2004. 6 c. URL : http : // www. who.int/ substance

abuse/research_tools/en/russian whoqol.pdf

5. Лобань Г.А., Зачепило С.В., Коваленко Н.П.

Формування здорового способу життя студентів як запорука суспільного та економічного розвитку держави. Актуальні проблеми сучасної медицини. 2015. T. 15, № 2. С. 30-32.

6. Неинфекционные заболевания. Информационный бюллетень Апрель 2017 г. URL : http://www. who.int/mediacentre/factsheets/fs355/ru/.
7. Yakymenko I., Tsybulin O., Shapovalov Ye. Healthy lifestyle behaviors among university students in Ukraine. Довкілля та здоров'я. 2017. № 1. Р. 41-45.

REFERENCES

1. Adamovych I.V., Vovk K.V., Litvin O.I., Nikolenko Ye.Ya. et al Aktualni problemy suchasnoi medytsyny. 2018 ; 18 (3) : 5-9 (in Ukrainian).

2. Tserkovna O., Barybina L., Filenko L. Et al. Sportyvna nauka Ukrainy. 2017 ; 2 (78) : 47-56 (in Ukrainian).

3. Zinoviev N.A, Zinoviev A.A., Kupreev M.V. and Sviatchenko P.B. Uchenye zapiski universiteta Lesgafta. 2015 ; 11 (129) : 42-47 (in Russian).

4. The World Health

Organization Quality of Life (WHOQOL) - BREF. 2004. $6 p$

URL : http : // www. who.int/ substance_abuse/research_tools/e n/russian_whoqol.pdf

(in Russian).

5. Loban G.A., Zachepylo S.V. and Kovalenko N.P. Aktualni problemy suchasnoi medytsyny. 2015 ; 15 (2) : 30-32

(in Ukrainian).

6. Noncommunicable diseases. WHO Fact sheets. URL : http://www. who.int/mediacentre/factsheets/fs355/ru/.

7. Yakymenko I., Tsybulin O. and Shapovalov Ye. Dovkillia ta zdorovia (Environment and Health). 2017. № 1.

Р. 41-45.

Надійшла до редакції 12.02.2019

Розподіл відповідей дівчат на запитання у різних групах обізнаності

Таблиця 6 щодо нераціонального харчування як фактора ризику розвитку НІЗ, \%

\begin{tabular}{|l|c|c|c|c|}
\hline \multicolumn{1}{|c|}{ Питання, що вивчалося } & \multicolumn{2}{c|}{ КНТЕУ } & \multicolumn{2}{c|}{ СумПУ } \\
\cline { 2 - 5 } & Обізнані & Не обізнані & Обізнані & Не обізнані \\
\hline Споживання солі на добу 25 г і більше & 25,8 & 29,6 & 22,5 & 36,8 \\
\hline Споживання солодких газованих напоїв & 68 & 74 & 57,9 & 89,5 \\
\hline Додають до чаю та кави 2 ложки цукру і більше & 29 & 29,6 & 43 & 47,4 \\
\hline Споживання маргаринів та спредів & 25,8 & 44,4 & 35,8 & 21,1 \\
\hline Відсутність у щоденному раціоні свіжих фруктів та овочів & 22,3 & 51,8 & 28,5 & 26,3 \\
\hline
\end{tabular}

Розподіл відповідей юнаків на запитання у різних групах обізнаності Таблиця 7 щодо нераціонального харчування як фактора ризику розвитку НІз

\begin{tabular}{|l|c|c|c|c|}
\hline \multicolumn{1}{|c|}{ Питання, що вивчалося } & \multicolumn{2}{c|}{ КНТЕУ } & \multicolumn{2}{c|}{ СумДПУ } \\
\cline { 2 - 6 } & Обізнані & Не обізнані & Обізнані & Не обізнані \\
\hline Споживання солі на добу 25 гі більше & 31,5 & 37,5 & 29,4 & 33,3 \\
\hline Споживання солодких газованих напоїв & 92 & 93 & 79,4 & 83,3 \\
\hline Додають до чаю та кави 2 ложки цукру і більше & 41 & 68 & 79,4 & 66,6 \\
\hline Споживання маргаринів та спредів & 25,8 & 31 & 41,2 & 33,3 \\
\hline Відсутність у щоденному раціоні свіжих фруктів та овочів & 25 & 44 & 35,3 & 58,3 \\
\hline
\end{tabular}

